\title{
Phytochemical Profile and Antioxidant Activity of Guazuma ulmifolia Leaves Extracts Using Different Solvent Extraction
}

\author{
Mohamad Rafi ${ }^{1,2, *}$, Nadya Meitary ${ }^{3}$, Dewi Anggraini Septaningsih ${ }^{2,4}$, Maria Bintang ${ }^{3}$
}

1. Department of Chemistry, Faculty of Mathematics and Natural Sciences, IPB University, Jalan Tanjung Kampus IPB Dramaga, Bogor 16880, Indonesia

2. Tropical Biopharmaca Research Center, IPB University, Jalan Taman Kencana No. 3 Kampus IPB Taman Kencana, Bogor 16128, Indonesia

3. Department of Biochemistry, Faculty of Mathematics and Natural Sciences, IPB University, Jalan Tanjung Kampus IPB Dramaga, Bogor 16880, Indonesia

4. Advance Research Laboratory, IPB University, Jalan Palem Kampus IPB Dramaga, Bogor 16680, Indonesia

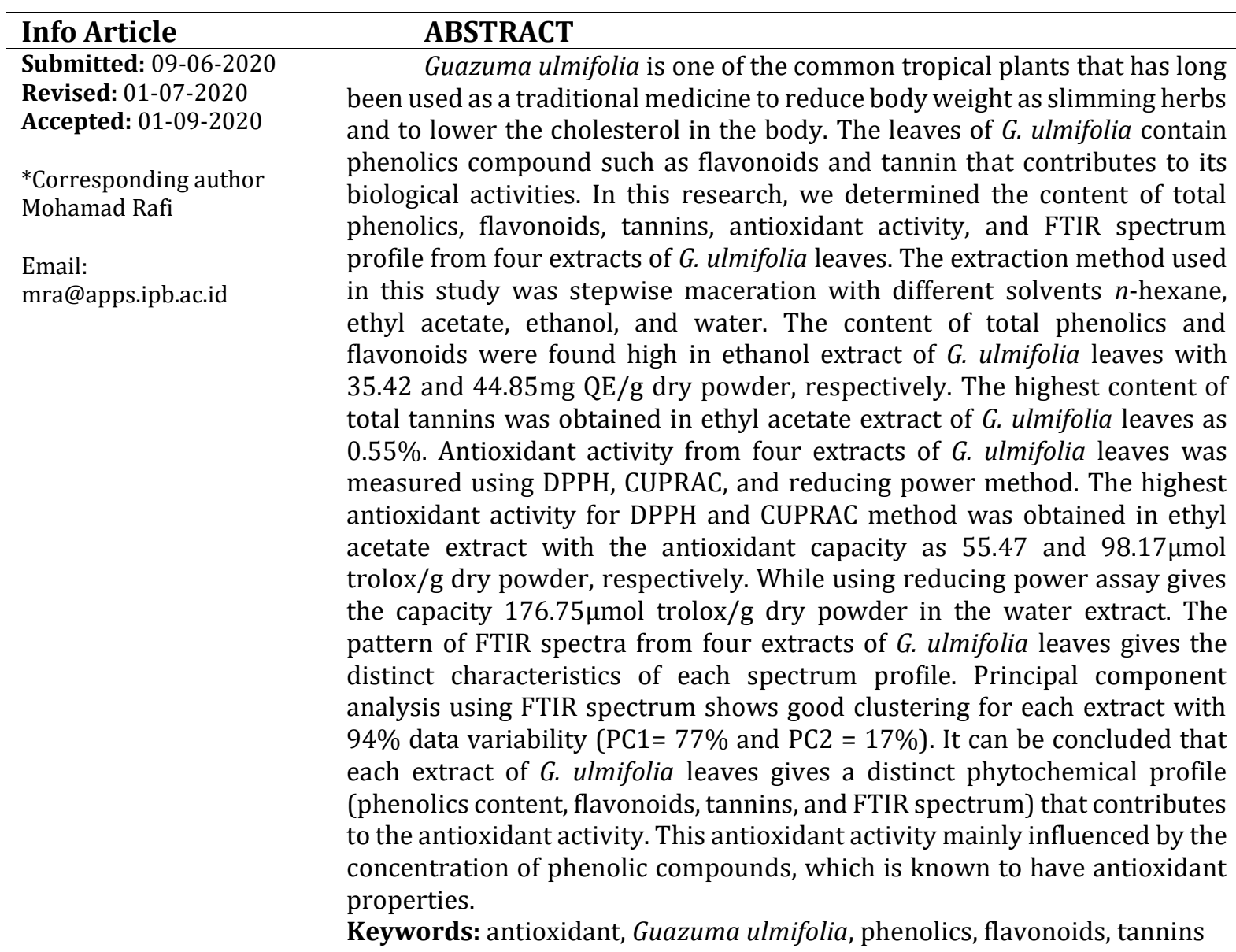

\section{INTRODUCTION}

Traditional medicine derived from plants is one way to utilize natural resources to maintain good health and to treat diseases in the community. One common plant that has been used as traditional medicine is Guazuma ulmifolia, known as bastard cedar, and it belongs to the family of Sterculiaceae. The proven pharmacological activity from this plant involve antiulcer (Berenguer et al., 2007), antihypertensive (Magos et al., 2008), antidiabetic (Adnyana et al., 2013), antioxidant, anticholinesterase, antibiotic-modulating antifungal (Morais et al., 2017), analgesic and antiinflammatory activities (Damor et al., 2018). The utilization of G. ulmifolia as traditional medicine can be linked to the presence of chemical 
compounds such as flavonoid, alkaloid, glycosides, phytosterol, and saponin responsible to its particular biological activity. Phytochemical composition and its concentration are greatly affected by some factors, such as genetics, environmental growth conditions, harvest, and post-harvest treatment. Extraction of metabolites using a different method and solvent extraction also play an essential role in the level of metabolites extracted (Rafi et al., 2020). Consistency in the composition and concentration level of bioactive compounds will give consistent biological activity. G. ulmifolia rich in phenolic compounds such as phenolic acid, flavonoid, and tannin, and those compounds have been known for their potency as an antioxidant (Pereira et al., 2019). Antioxidant compounds within plant extracts having different molecular structures and polarities. Based on its molecular structure, antioxidant compounds with its chemical characteristics and polarities may or may not be soluble in a solvent. Polar solvents are frequently used for the polyphenol extraction from plant matrices (Altemimi et al., 2017). Ethanol and water as polar solvents are well known for polyphenol extraction and safe for human consumption. Ethyl acetate has a medium polarity and low toxicity that could extract many antioxidant compounds from polar to nonpolar.

From the previous studies, many papers have been reported the composition and concentration of metabolite or compound class present in G. ulmifolia with a particular biological activity (Maldini et al., 2013; Morais et al., 2017; Prahastuti et al., 2020). However, there is no reported paper for extracting metabolites in $G$. ulmifolia with different solvent extraction using stepwise maceration for knowing the phytochemical profile and antioxidant activity. In this study, we have investigated the phytochemical profile and antioxidant activity of G. ulmifolia using the various polarity of solvents ( $n$-hexane, ethyl acetate, ethanol, and water). We also make a correlation between antioxidant activities and phytochemical (phenolics, flavonoid, and tannin) content to show its contribution toward antioxidant activities. By mapping the phytochemical profile and antioxidant activity of different $G$. ulmifolia extracts, we will have better information about each extract's characteristics.

\section{MATERIAL AND METHODS}

G. ulmifolia leaves were obtained from Tropical Biopharmaca Research Center (TropBRC) IPB University, Bogor, Indonesia. Mr. Taopik
Ridwan identified the plant, and the voucher specimens were stored in TropBRC, IPB University. Methanol, ethanol, $n$-hexane, ethyl acetate, FolinCiocalteu (FC) reagent, sodium carbonate, potassium permanganate, aluminum (III) chloride, potassium acetate, copper (II) chloride, potassium ferricyanide $\left(\mathrm{K}_{3} \mathrm{Fe}(\mathrm{CN})_{6}\right)$, trichloroacetic acid (TCA) were obtained from Merck (Darmstadt, Germany). Gallic acid, quercetin, trolox, neocuproine, indigo carmine, 2,2-diphenyl-1picrylhydrazyl (DPPH) were purchased from Sigma-Aldrich (St. Louis, MO, USA).

\section{Sample preparation and extraction}

G. ulmifolia leaves were dried, pulverized into a powder, and then sieved with 100 mesh particle size. Extraction was performed using a procedure described in Indonesian Herbal Pharmacopoeia $1^{\text {st }}$ edition (Ministry of Health Republic of Indonesia, 2008). About 20g of samples were macerated with $200 \mathrm{~mL} n$-hexane for $24 \mathrm{~h}$ at room temperature. After continuous stirring of samples for $6 \mathrm{~h}$, samples left for a further $18 \mathrm{~h}$ without stirring. The filtrate was collected and concentrated with a rotary evaporator at $50^{\circ} \mathrm{C}$. The residue from the filtration process with $n$-hexane was then extracted with ethyl acetate, and the obtained filtrate was concentrated. Next, the residue from the previous filtration was then extracted with ethanol until the filtrate was obtained. The residue from previous ethanol filtration was then macerated and extracted with water using the reflux method until obtained the concentrated filtrate. The extraction process using each solvent ( $n$-hexane, ethyl acetate, ethanol, and water) was repeated three times. Then the resulted of concentrated filtrate from each solvent was weighed to measure its yield.

\section{Determination of total phenolics}

The total phenolics content (TPC) in each extract of G. ulmifolia leaves was determined using the Folin-Ciocalteu method using a procedure described by Rafi et al., (2018). Each of n-hexane, ethyl acetate, ethanol, and water extract were pipetted $10 \mu \mathrm{L}$ into 96 well plates. Then approximately $160 \mu \mathrm{L}$ distilled water, $10 \mu \mathrm{L}$ of $10 \%$ FC reagent, and $20 \mu \mathrm{L}$ of $7.5 \% \mathrm{Na}_{2} \mathrm{CO}_{3}$ was added subsequently into each extract in the 96 well plates. The mixture was then homogenized and incubated for $30 \mathrm{~min}$ at room temperature. The maximum absorbance of the mixture was measured at $750 \mathrm{~nm}$ using a microplate reader (Epoch-BioTek, Winooski, USA). The calibration curve was 
prepared by diluting gallic acid in ethanol in 5 different concentrations as $10,30,50,70,100$ (mg/L). TFC of each extract was expressed as milligram gallic acid equivalent per gram dry powder of G. ulmifolia (mg GAE/g dry powder).

\section{Determination of total flavonoids}

The total flavonoids content (TFC) of each extract was investigated using the aluminum chloride colorimetry method following the procedure described by Lee et al., (2011). Each of $10 \mu \mathrm{L}$ extract from $n$-hexane, ethyl acetate, ethanol, and water from $G$. ulmifolia leaves was added with $60 \mu \mathrm{L}$ ethanol, $10 \mu \mathrm{L}$ of $10 \% \mathrm{AlCl} 3,10 \mu \mathrm{L}$ of $1 \mathrm{M}$ $\mathrm{CH}_{3} \mathrm{COOK}$, and $120 \mu \mathrm{L}$ distilled water subsequently into 96 well plates. The mixture was homogenized and incubated for $30 \mathrm{~min}$ at room temperature. Then the absorbance of the mixture was at $415 \mathrm{~nm}$ using a microplate reader (Epoch-BioTek, Winooski, USA). The calibration curve was prepared by diluting quercetin in ethanol in 7 different concentrations as 20,40,60, 80, 100, 120, $140(\mu \mathrm{g} / \mathrm{mL})$. TFC was expressed as milligram quercetin equivalent per gram dry powder of $G$. ulmifolia leaves (mg QCE/g dry powder).

\section{Determination of total tannins}

The total tannins content (TTC) in each extract was determined using the procedure described Indonesian Herbal Pharmacopoeia $1^{\text {st }}$ edition (Ministry of Health Republic of Indonesia, 2008). Each of $0.2 \mathrm{~g}$ extract from $G$. ulmifolia leaves was added into $250 \mathrm{~mL}$ Erlenmeyer flask and heated for $30 \mathrm{~min}$. Then the mixture left for $10 \mathrm{~min}$ and filtered until obtained residue. The process was repeated to make sure all the tannins were extracted from the residue. Next, $2.5 \mathrm{~mL}$ of the mixture was added with $2.5 \mathrm{~mL}$ of indigo carmine and diluted into $100 \mathrm{~mL}$ volume with water. Then, the solution was titrated with $0.1 \mathrm{~N} \mathrm{KMnO}_{4}$ until obtained the color solution changing into golden yellow. The blank solution was prepared with a similar procedure but without adding the extract. Approximately $1 \mathrm{~mL}$ of $0.1 \mathrm{~N} \mathrm{KMnO}_{4}$ is equivalent to $0.004 \mathrm{~g}$ tannins. Total tannins can be calculated as follow:

\begin{tabular}{|c|c|}
\hline \multirow{2}{*}{$\begin{array}{l}\% \text { total } \\
\text { Tannin }=\end{array}$} & $\underset{(\mathrm{mL})}{\mathrm{V} \mathrm{KMnO}_{4} \text { sample }-\mathrm{V} \mathrm{KMnO}_{4} \text { blank }}$ \\
\hline & weight extract (g) \\
\hline$x \frac{0.00}{1 \mathrm{~m}}$ & $\frac{4 \mathrm{~g}}{\mathrm{~L}} \times 100 \%$ \\
\hline
\end{tabular}

\section{DPPH radical scavenging activity}

The antioxidant activity of the extract was measured with the DPPH method following the procedure described by Salazar-Arandra et al., (2009). Each of $40 \mu \mathrm{L}$ extract was added with $120 \mu \mathrm{L}$ of $125 \mu \mathrm{mol} / \mathrm{L}$ freshly prepared DPPH solution into 96 well plates. Then the mixture was incubated in the dark for $30 \mathrm{~min}$ at room temperature. The decrease in absorbance was measured at $515 \mathrm{~nm}$ using a microplate reader (Epoch-BioTek, Winooski, USA). Negative control was prepared by mixing $40 \mu \mathrm{L}$ ethanol with $120 \mu \mathrm{L}$ of $125 \mu \mathrm{mol} / \mathrm{L}$ freshly prepared DPPH solution. While positive control used trolox and prepared in 9 consecutive concentrations as 50,75, 100, 150, 200, 250, 300, $350,400 \mu \mathrm{M}$. The measurement was repeated three times, and the capacity to scavenge the DPPH radical was expressed in $\mu$ mol trolox/g dry powder.

\section{Cupric ion reducing antioxidant capacity}

The cupric ion reducing antioxidant capacity (CUPRAC) of the extracts was determined to the CUPRAC method described by Ozturk et al., (2011). To each well, in a 96 well plate, $40 \mu \mathrm{L}$ of the extracts, $50 \mu \mathrm{L}$ of $10 \mathrm{mM} \mathrm{CuCl}_{2}, 50 \mu \mathrm{L}$ of $7.5 \mathrm{mM}$ neocuproine, and $60 \mu \mathrm{L} \mathrm{NH}_{4} \mathrm{CH}_{3} \mathrm{COO}$ buffer (1M, pH 7) solutions were added subsequently. Then the mixture was incubated for $1 \mathrm{~h}$ at room temperature. After $1 \mathrm{~h}$, the absorbance at $450 \mathrm{~nm}$ was recorded against a reagent blank by using a 96-well microplate reader (Epoch-BioTek, Winooski, USA). The calibration curve was prepared with trolox in 5 different concentrations as 100, 200, 300, 400, $600(\mu \mathrm{M})$. The antioxidant capacity was expressed in $\mu \mathrm{mol}$ trolox/g dry powder.

\section{Reducing power assay}

The ability of the extracts to reduce ferric ions $\left(\mathrm{Fe}^{3+}\right)$ was assessed with the method described by Benslama and Harrar (2006). Approximately $400 \mu \mathrm{L}$ of the extract was added with $200 \mu \mathrm{L}$ phosphate buffer $(0.2 \mathrm{M}, \mathrm{pH} 6.6)$ and $400 \mu \mathrm{L}$ of $1 \%$ potassium ferricyanide $\left[\mathrm{K}_{3} \mathrm{Fe}(\mathrm{CN})_{6}\right]$ then the mixture was incubated at $50^{\circ} \mathrm{C}$ for $20 \mathrm{~min}$. Next, about $400 \mu \mathrm{L}$ of trichloroacetic acid was added into the mixture and centrifuged for 10 minutes at $3000 \mathrm{rpm}$. Finally, $200 \mu \mathrm{L}$ of the supernatant solution was mixed with $400 \mu \mathrm{L}$ of distilled water, and $40 \mu \mathrm{L}$ of $0.1 \% \mathrm{FeCl}_{3}$ and the absorbance was recorded at $700 \mathrm{~nm}$ using a microplate reader. The calibration curve was prepared using a trolox solution in 5 different concentrations as 200,400, 600, 800, $1000(\mu \mathrm{M})$. 
The antioxidant capacity was expressed in $\mu \mathrm{mol}$ trolox/g dry powder.

\section{FTIR Spectra and Classification of G. ulmifolia extracts}

About $2 \mathrm{mg}$ of G. ulmifolia leaves extract were mixed with $200 \mathrm{mg}$ of $\mathrm{KBr}$ and then homogenized and formed into a pellet using a Shimadzu hand press (pressure 8 tons for 10min). The measurement of the FTIR spectrum was performed at the mid-IR area $\left(4000-400 \mathrm{~cm}^{-1}\right)$ involving a personal computer equipped with OPUS software version 4.2. The IR spectrum was recorded with a scan speed of $32 \mathrm{~s} / \mathrm{min}$, and a resolution of $4 \mathrm{~cm}^{-1}$ with a data display contains 1866 points of absorption. The IR spectra were further used for the classification of G. ulmifolia extracts. We used principal component analysis (PCA) to classify $t$ he G. ulmifolia extracts with The Unscrambler X software version 10.1 (CAMO, Oslo, Norway). Before subjected to the PCA, the IR spectra were preprocessed using standard normal variate (SNV).

\section{Statistical analysis}

The experimental data were done in triplicate measurements and reported as mean \pm standard deviation. Statistical comparisons were performed using a one-way analysis of variance (ANOVA) followed by Duncan test. A significant difference was defined at the $95 \%$ confidence level $(p<0.05)$. Correlation of phytochemical content with antioxidant activity and clustering of the $G$. ulmifolia extracts were performed using Pearson correlation and principal component analysis (PCA), respectively. All the statistical analysis was performed in Unscrambler X version 10.1 (CAMO, Oslo, Norway).

\section{RESULTS AND DISCUSSION \\ Extraction yield}

Extraction is the first step to recover and isolate the bioactive phytochemical compounds from the plant materials. The extraction efficiency from plant materials is influenced by several factors, including the chemical nature of phytochemicals, the extraction method used, size of sample particle, and the presence of interfering substances (Stalikas 2007). The extraction yield depends on the $\mathrm{pH}$, temperature, extraction time, solvent polarity, and sample composition. The sample composition and solvent polarity are regarded as the critical parameters under similar time extraction and temperature (Do et al., 2014).
In this work, the extracts of G. ulmifolia leaves were obtained by using various range polarity of solvent from nonpolar ( $n$-hexane) to polar (water). Extraction yields ranged from $18.24 \%$ for ethanol extract to $5.73 \%$ for $n$-hexane extract. It is also can be seen that the extraction yield of water (10.94\%) is higher than ethyl acetate $(9.08 \%)$. The average yields of extraction by various solvents decreased in the following order: ethanol > water $>$ ethyl acetate $>n$-hexane. These results show that the extraction yield increases with increasing polarity of the solvent used in the extraction process of $G$. ulmifolia leaves. Compounds such as proteins and carbohydrates may have been extracted in water and ethanol and contribute to higher yield rather than in ethyl acetate and $n$-hexane.

\section{Total phenolics, total flavonoids and total tannins of G. ulmifolia leaves extracts}

Total phenolics content from different extracts ( $n$-hexane, ethyl acetate, ethanol, and water) of G. ulmifolia leaves (Table I). The TPC of different extracts was measured with the FC method using gallic acid as a positive control. The TPC of the extracts range from $13.00 \mathrm{mg} \mathrm{GAE} / \mathrm{g}$ dry powder for $n$-hexane extract to $35.42 \mathrm{mg} \mathrm{GAE} / \mathrm{g}$ dry powder for ethanol extract, and they decrease in the following order: ethanol $>$ water $>$ ethyl acetate $>n$-hexane. The TPC of the ethyl acetate extract (16.74 mg GAE/g dry powder) is not significantly higher than that of the water extract $(16.97 \mathrm{mg}$ GAE/g dry powder), whereas the TPC of the $n$ hexane extract is significantly less than the other solvents $(p<0.05)$. It can be due to the higher solubility of a non-phenolics compound such as carbohydrate in water extracts rather than in ethyl acetate and $n$-hexane extracts. The TPC of the ethanol extracts gives the highest value due to the possible complex formation of some phenolics compound in the extract that are soluble in this solvent. These phenolics compound may have higher molecular weights solubilized in the ethanol and contain more phenolics group than the phenolics in the water extracts (Do et al., 2014). It can be concluded from the results of TPC from different extract, and ethanol was the best extracting solvent to solubilize the phenolics compound from the extract of $G$. ulmifolia leaves.

Total flavonoids content from different extracts ( $n$-hexane, ethyl acetate, ethanol, and water) of G. ulmifolia leaves (Table I). The TFC of different extracts was measured using $\mathrm{AlCl}_{3}$ reagent and quercetin as a positive control using the UV-Vis spectrophotometry method. 
Table I. The total phenolics, flavonoids and tannin content in the four extract of G. ulmifolia leaves $(\mathrm{n}=3)$

\begin{tabular}{cccc}
\hline Extract & $\begin{array}{c}\text { Total phenolics } \\
\text { (mg GAE/g dry powder) }\end{array}$ & $\begin{array}{c}\text { Total flavonoids } \\
\text { (mg QE/g dry powder) }\end{array}$ & $\begin{array}{c}\text { Total tannin } \\
\text { (\%) }\end{array}$ \\
\hline n-hexane & $13.00^{\mathrm{a}} \pm 0.84$ & $21.46^{\mathrm{b}} \pm 0.59$ & $0.14^{\mathrm{a}} \pm 0.06$ \\
Ethyl acetate & $17.74^{\mathrm{b}} \pm 1.11$ & $31.71^{\mathrm{c}} \pm 0.01$ & $0.55^{\mathrm{c}} \pm 0.06$ \\
Ethanol & $35.42^{\mathrm{c}} \pm 2.67$ & $44.85^{\mathrm{d}} \pm 3.55$ & $0.45^{\mathrm{bc} \pm 0.06}$ \\
Water & $16.97^{\mathrm{b}} \pm 2.41$ & $14.15^{\mathrm{a}} \pm 1.10$ & $0.35^{\mathrm{b} \pm 0.16}$ \\
\hline
\end{tabular}

*the letter denotes significance test at $\mathrm{p}<0.05$ Duncan method

Table II. The capacity of antioxidant activity with different methods of DPPH, CUPRAC, and reducing power assay $(\mathrm{n}=3)$

\begin{tabular}{cccc}
\hline \multirow{2}{*}{ Extract } & \multicolumn{2}{c}{ Antioxidant capacity ( $\boldsymbol{\mu m o l}$ trolox/g dry powder) } \\
\cline { 2 - 4 } & DPPH & CUPRAC & Reducing power \\
\hline$n$-hexane & $9.03^{\mathrm{a} \pm 0.44}$ & $21.86^{\mathrm{a}} \pm 1.86$ & $70.90^{\mathrm{ab}} \pm 5.61$ \\
Ethyl acetate & $55.47^{\mathrm{d}} \pm 1.87$ & $98.17^{\mathrm{d}} \pm 7.89$ & $50.35^{\mathrm{a} \pm 5.72}$ \\
Ethanol & $21.36^{\mathrm{b}} \pm 0.30$ & $35.52^{\mathrm{b}} \pm 1.68$ & $92.11^{\mathrm{c}} \pm 5.34$ \\
Water & $37.41^{\mathrm{c}} \pm 3.88$ & $58.79^{\mathrm{c}} \pm 2.81$ & $176.75^{\mathrm{d} \pm 13.26}$ \\
\hline
\end{tabular}

The TFC of extracts range from $14.15 \mathrm{mg} Q \mathrm{Q} / \mathrm{g}$ dry powder for water extract to $44.85 \mathrm{mg} \mathrm{QE} / \mathrm{g}$ dry powder for ethanol extract and they decrease in the following order: ethanol $>$ ethyl acetate $>n$-hexane $>$ water. The results of TFC in G. ulmifolia leaves were entirely synchronous with those obtained from the analysis of total phenolic in different extracts. It was successfully shown that samples with a high phenolics content in the extract of $G$. ulmifolia leaves also contain flavonoids in a considerable amount. The rich-flavonoid plants could be an excellent antioxidant source that would help improve the total antioxidant capacity of an organism and prevent it from the lipid peroxidation (Esmaili et al., 2015).

Total tannins content from the extracts of $G$. ulmifolia leaves in different solvents (Table I). The TTC from the extracts was measured using permanganometric titration with indigo carmine sulphonate as a dye indicator. Total tannins level from different extracts of G. ulmifolia leaves have low-level content compared to total phenolics and flavonoids. By comparing the results with various solvents (Table II), we can see that the total phenolics, flavonoids, and tannins content are greatly depending on the solvent polarity. The maceration and extraction of G. ulmifolia leaves with ethanol solvent give the highest total phenolics, flavonoids, and tannins content in the extract.

\section{Antioxidant Activity of G. ulmifolia Leaves Extracts}

Antioxidant activity of $G$. ulmifolia extracts was determined using three methods, namely DPPH, CUPRAC, and reducing power assay. In the DPPH method, 2,2-Diphenyl-1-picrylhydrazyl was used as a stable organic free radical reagent with the highest absorption band at $517 \mathrm{~nm}$. The absorption of this radical species is lost when an electron or a free radical species is accepted, resulting in a visual discoloration from purple to yellow. This radical species can also combine with many samples in a short time and is sensitive to distinguish active ingredients at low concentrations (Esmaili et al., 2015).

DPPH radical scavenging ability of in vitro from the extracts of $G$. ulmifolia leaves with different extraction solvents (Table II). The $n$ hexane extract from $G$. ulmifolia leaves showed a reading of the lowest of DPPH radical scavenging (9.03 $\mu \mathrm{mol}$ trolox/g dry powder), while the highest one belonged to the ethyl acetate extract $(55.47 \mu \mathrm{mol}$ trolox/g dry powder). Although the DPPH radical scavenging activities from the extracts of different solvents were less than those observed at Trolox as a standard reference compound, this study reveals that $G$. ulmifolia leaves have free radical scavengers or inhibitors possibly acting as a primary antioxidant. 
Table III. Pearson correlation phenolic, flavonoids, tannin content and antioxidant activity.

\begin{tabular}{ccccc}
\hline Extract & Variable & Reducing Power & Cuprac & DPPH \\
\hline \multirow{3}{*}{$n$-Hexane } & Tannins & 0.552 & -0.907 & -0.927 \\
& Flavonoids & 0.986 & -0.314 & -0.908 \\
& Phenol & -0.978 & 0.350 & 0.924 \\
& Tannins & 0.306 & -0.858 & 0.914 \\
Ethyl Acetat & Flavonoids & -0.977 & -0.015 & -0.107 \\
& Phenol & -0.746 & -0.818 & 0.741 \\
& Tannins & -0.434 & -0.987 & 0.009 \\
Ethanol & Flavonoids & -0.979 & -0.395 & -0.968 \\
& Phenol & 0.673 & 0.992 & 0.276 \\
& Tannins & -0.411 & -0.392 & -0.925 \\
& Flavonoids & -0.007 & 0.014 & -0.692 \\
& Phenol & 0.360 & 0.341 & 0.903 \\
\hline
\end{tabular}

Another simple and versatile method to measure the antioxidant capacity from the extract of G. ulmifolia leaves is the CUPRAC method using a cupric neocuproine (2,9-dimethyl-1,10phenanthroline) chelate-abbreviated as ( $\mathrm{Cu}(\mathrm{II})$ $\mathrm{Nc}$ ) as the chromogenic oxidant. This method is based on the redox reaction with antioxidant compounds producing the cuprous-neocuproine chelate-abbreviated as (Cu(I)-Nc)- showing maximum light absorption at $450 \mathrm{~nm}$ (Apak et al., 2004). The reaction of the chromogenic reagent with n-electron reductant (AO) from antioxidant compounds producing a stable orange yellow color within $30 \mathrm{~min}$ following in the manner (Apak et al., 2008).

Antioxidant compounds that are expected to be found in G. ulmifolia leaves, namely phenolics, flavonoids, and tannins were used in standard solutions and assayed using the normal (at room temperature) and incubated against trolox as the standard reference compound. In this study, the antioxidant capacity using the CUPRAC method from the extract of G. ulmifolia leaves range from $21.86 \mu \mathrm{mol}$ trolox/g dry powder for $n$-hexane extract to $98.17 \mu \mathrm{mol}$ trolox/g dry powder for ethyl acetate extract. The antioxidant capacity of the extracts assessed by the CUPRAC method decrease in the following order: ethyl acetate > water > ethanol $>n$-hexane. The establishment of the antioxidant capacity of G. ulmifolia leaves will promote research on the identification and quantitation of active compounds of this plant, which may help protect consumers against oxidative stress-related diseases.

The reduction power from the extract of $G$. ulmifolia leaves, which potentially serves as a significant antioxidant activity, was calculated using $\mathrm{Fe}^{3+}$ to $\mathrm{Fe}^{2+}$ reduction assay, whereby the initial color was yellow changes to various shades of green and blue depending on the reducing power of the samples. In this assay, the presence of antioxidant compounds leads to $\mathrm{Fe}^{3+}$ /ferricyanide complex reduced to the $\mathrm{Fe}^{2+}$ form, and $\mathrm{Fe}^{2+}$ can be monitored through the measurement of the formation of Perl's Prussian blue at $700 \mathrm{~nm}$ (Qingming et al., 2010). Antioxidant capacity from the extract of $G$. ulmifolia leaves using reducing power method varied from $50.35 \mu \mathrm{mol}$ trolox/g dry powder for ethyl acetate extract to $176.75 \mu \mathrm{mol}$ trolox/g dry powder for water extract. It can be concluded that the water extract could act as electron donors and convert free radicals to more stable products (Table II). Some of the phenolic compounds, such as flavonoids and phenolic acids in the water extracts exhibited strong antioxidant activity through their reductive capacity in $\mathrm{Fe}^{3+}$ $\mathrm{Fe}^{2+}$ system.

\section{Correlation between phytochemical content and antioxidant activity}

The correlation between phytochemical levels on the antioxidant activity of four $G$. ulmifolia leaves extracts was carried out using the Pearson correlation. The parameter used was the correlation coefficient (R) between the levels of phytochemical compounds (total phenolics, flavonoids, and tannins) in each extract with antioxidant activity. The higher the R-value, the higher the correlation between variables. Linear regression with the $\mathrm{X}$-axis (levels of phytochemical compounds) and the Y-axis (antioxidant capacity) was used to see the correlation of phytochemical compounds to antioxidant activity in four $G$. ulmifolia extracts (Table III). 


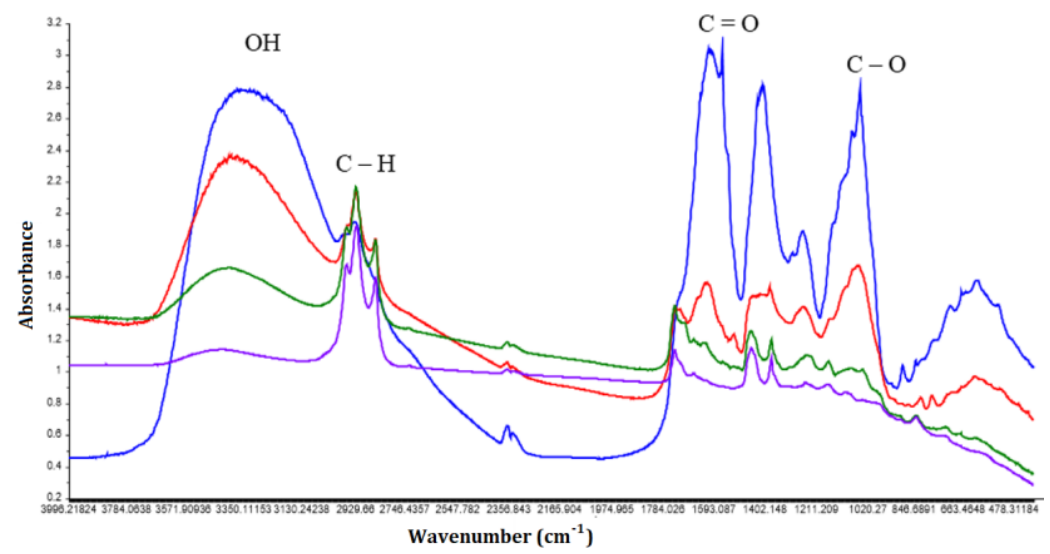

Figure 1. Representative of FTIR spectrum derived from extract of $G$. ulmifolia leaves (- water, - ethanol, ethyl acetate, $-n$-hexane)
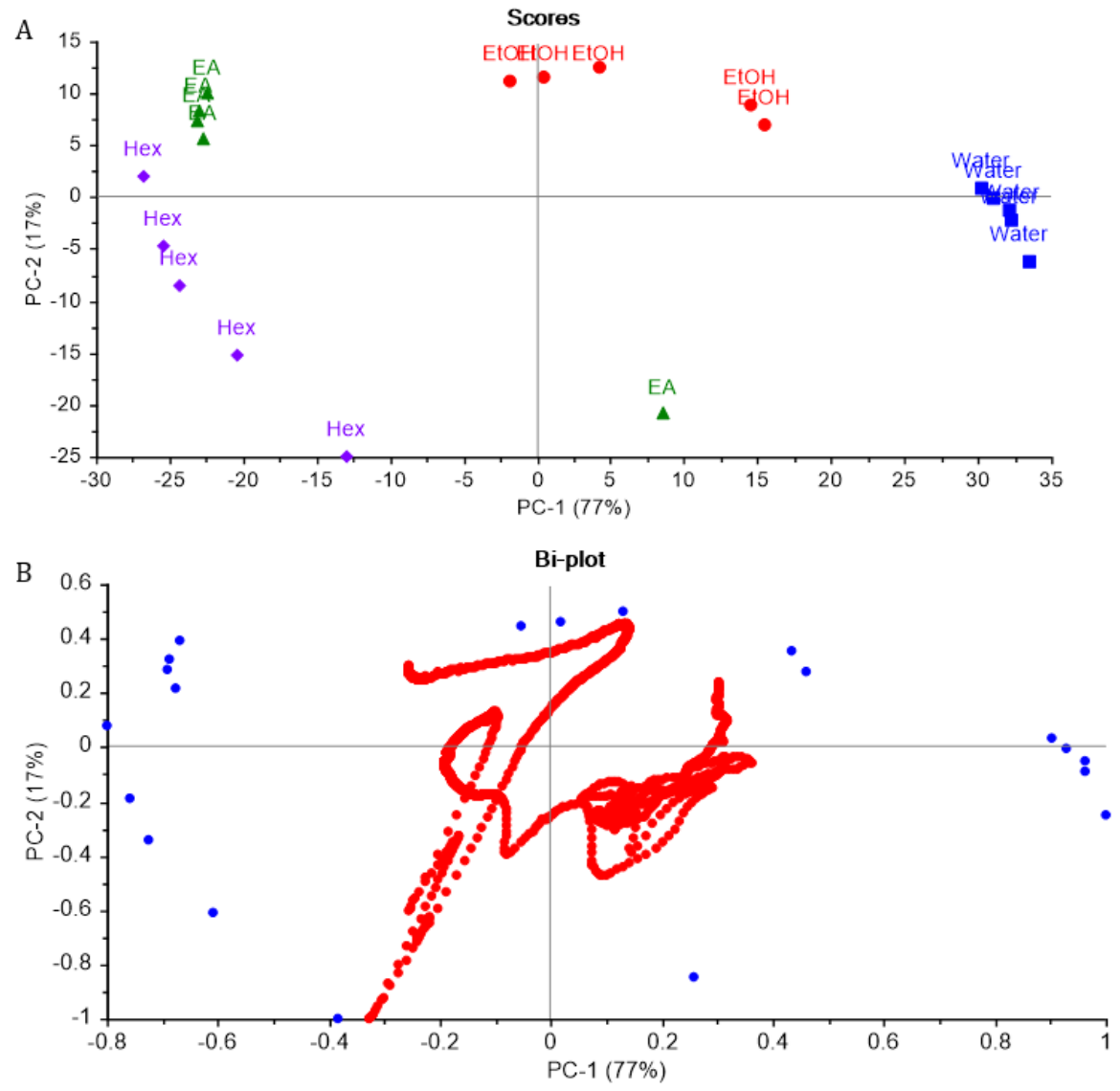

Figure 2. The score plot (A) and loading plot (B) of PCA derived from extract of G. ulmifolia leaves using variable mid-IR area $\left(4000-400 \mathrm{~cm}^{-1}\right)(\bullet=$ ethanol, $\boldsymbol{\bullet}=$ water, $\bullet=n$-hexane, $\Delta=$ ethyl acetate $)$ 
Based on the Pearson correlation, a positive correlation was shown by the levels of total flavonoids and phenolics of $n$-hexane extract on the reducing power and DPPH methods' antioxidant capacity. The antioxidant capacity of ethyl acetate extract was influenced by total tannins and phenolics levels with a positive correlation of 0.914 and 0.741, respectively, using the DPPH method. Whereas in ethanol and water extracts, total phenolics content had a positive correlation with antioxidant capacity with the three methods used with the highest values in the CUPRAC and DPPH methods. These results explain that the phenolics group compounds significantly affect the antioxidant activity in ethanol and water extracts compared to other extracts. The role of nonphenolic secondary metabolites can also influence the determination of the antioxidant activity of the teak leaves because the three methods of antioxidant activity that are carried out are not specific to the phenolic group compounds. Also, individual phenolic compounds may have different antioxidant activities, and their interactions with macromolecules such as carbohydrates and proteins may be synergistic or antagonistic (Odabasoglu et al., 2005).

\section{Classification of $G$. ulmifolia Leaves Extracts by FTIR Spectra and Chemometrics Analysis}

Classification of G. ulmifolia leaves extracts with different solvent extraction was done using FTIR spectra combined with chemometrics. Comparison of spectra of different extracts using $n$ hexane, ethyl acetate, ethanol, and water solvents of G. ulmifolia leaves (Figure 1). Differences of spectral are observed between different extracts of G. ulmifolia leaves samples at 3500-3000, 3000$2800,1750-1500$, and $1200-1000 \mathrm{~cm}^{-1}$ (Figure 1). Peak absorbance at $3500-3000 \mathrm{~cm}^{-1}$ corresponds to hydroxyl absorption, $3000-2800 \mathrm{~cm}^{-1}$ related to methylene $\mathrm{C}-\mathrm{H}$ asymmetric stretching vibration, $1750-1500 \mathrm{~cm}^{-1}$ is due to the stretching vibration of carbonyl group, and peaks around $1000 \mathrm{~m}^{-1}$ are the vibration peak of $\mathrm{C}-\mathrm{O}$ an alcohol group.

The principal component analysis (PCA) of the FTIR spectral data with 1866 variables is displayed in a two-dimensional plot using the first two principal components (Figure 2A), which together accounted for PC1 (77\%) and PC2 (17\%) of the $94 \%$ total variation. The PCA score plot indicated that PCA had a relatively high distinguishing capacity between $G$. ulmifolia leaves with four different solvents for the extraction process as a dependent manner. The sample of $G$. ulmifolia leaves can be classified using the loading values for the essential spectral variables (i.e., those with the highest variation on PC1 and PC2 scores). The loading plot shows the $n$-hexane extract of G. ulmifolia leaves differentiated from other extracts in the wavenumber at 2900-2950 $\mathrm{cm}^{-1}$. Ethyl acetate, ethanol, and water extract were differentiated at $2800-2870 \mathrm{~cm}^{-1}, 3000-3300 \mathrm{~cm}^{-1}$, and $1000-1050 \mathrm{~cm}^{-1}$ (IR fingerprint area). These results indicate that the qualitative and quantitative changes of phytochemical compounds in G. ulmifolia leaves corresponding to these spectral regions in FTIR spectra were significant variations related to the choice of solvent extraction.

\section{CONCLUSIONS}

In this study, the ethanol extract of $G$. ulmifolia leaves have the highest total phenolics and flavonoids content. In contrast, ethyl acetate extract has a higher level of total tannins compared to other extracts used in this study. Moreover, we showed that the highest antioxidant capacity of $G$. ulmifolia leaves found in the ethyl acetate extract assessed by the DPPH and CUPRAC methods. Classification of $G$. ulmifolia leaves extracts using FTIR spectra and PCA showed good clustering with $94 \%$ of total variance data between 4 different solvents ( $n$-hexane, ethyl acetate, ethanol, and water) for the extraction process. It can be concluded that each extract of G. ulmifolia leaves gives a distinct phytochemical profile (total phenolics, total flavonoids, total tannins, and FTIR spectrum) that contributes to the antioxidant activity. This antioxidant activity is mainly influenced by the concentration of phenolics compounds known to have antioxidant activity. Therefore, we suggest that the screening of phytochemical compounds related to the assessment of its bioactivity and combined with chemometric analysis derived from FTIR spectra from the sample extract could give a more comprehensive knowledge of medicinal plant study.

\section{ACKNOWLEDGMENT}

\section{REFERENCES}

Adnyana IK., Sukandar EY., Susanto Y., Kurniati NF. 2013. Antidiabetic activity of aqueous leaf extracts of Guazuma ulmifolia lamk., ethanolic extracts of Curcuma xanthorrhiza and their combinations in alloxan-induced diabetic mice. Res. J. Med. Plant. 7(3):158164 
Altemimi A., Lakhssassi N., Baharlouei A., Watson DG., Lightfoot DA. 2017. Phytochemicals: extraction, isolation, and identification of bioactive compounds from plant extracts. Plant. 6(4), 42-64.

Apak R., Güclü K., Özyürek M., Karademir SE. 2004. Novel total antioxidant capacity index for dietary polyphenols and vitamins $\mathrm{C}$ and $\mathrm{E}$, using their cupric ion reducing capability in the presence of neocuproine: CUPRAC method. J. Agric. Food Chem. 52(26):79707981.

Apak R., Güclü K., Özyürek M., Celik SE. 2008. Mechanism of antioxidant capacity assays and the CUPRAC (cupric ion reducing antioxidant capacity) assay. Microchim. Acta. 160:413-419.

Benslama A., Harrar A. 2016. Free radicals scavenging activity and reducing power of two algerian sahara medicinal plants extracts. Int. J. Herb. Med. 4(6):158-161.

Berenguer B., Sánchez-Fidalgo S., Trabadela C., Quilez AM. 2007. The aerial parts of Guazuma ulmifolia Lamk. protect against NSAID-induced gastric legions. J. Ethnopharmacol. 114(2):153-60.

Damor B., Gaur K., Dashora A., Parra SA. 2018. Evaluation of analgesic and antiinflammatory activity of methanolic extract of Guazuma ulmifolia. J. Appl. Pharm. Sci. Res. 1 (4): 23-29.

Do QD., Angkawijaya AE., Tran-Nguyen PL., Huynh LH., Soetaredjo FE., Ismadji S., Ju Y-H. 2014. Effect of extraction solvent on total phenol content, total flavonoid content, and antioxidant activity of Limnophilia aromatica. J. Food Drug Anal. 22(3):296302.

Esmaili AK., Taha RM., Mohajer S., Banisalam B. 2015. Antioxidant activity and total phenolic and flavonoid content of various solvent extracts from in vivo and in vitro grown Trifolium pratense L. (red clover). Biomed. Res. Int. 643285.

Lee SH., Sancheti SA., Bafna MR., Sancheti SS., Seo SY. 2011. Acetylcholineterase inhibitory and antioxidant properties of Rhododendron yedoense var. Poukhanense bark. J. Med. Plant Res. 5(2):248-254.

Magos GA., Mateos JC., Páez E., Fernández G., Lobato C., Márquez C., Enriquez RG. 2008. Hypotensive and vasorelaxant effects of the procyanidin fraction from Guazuma ulmifolia bark in normotensive and hypertensive rats. J. Ethnopharmacol. 117(1): 58-68.

Maldini M., Di Micco S., Montoro P., Darra E., Mariotto S., Bifulco G., Pizza C., Piacente S. 2013. Flavanocoumarins from Guazuma ulmifolia bark and evaluation of their affinity for STAT1. Phytochemistry. 86: 64-71.

Ministry of Health Republic of Indonesia. 2008. Indonesian Herbal Pharmacopoeia Ed.1. Jakarta (ID): Ministry of Health Republic of Indonesia.

Morais SM., Calixto-Júnior JT., Ribeiro LM., Sousa HA., Silva AAS., Figueiredo FG., Matias FFF., Boligon AA., Athayde ML., Morais-Braga MFB., Coutinho HDM. 2017. Phenolic composition and antioxidant, anticholinesterase and antibioticmodulating antifungal activities of Guazuma ulmifolia Lam. (Malvaceae) ethanol extract. S. Afr. J. Bot. 110: 251-257.

Odabasoglu F, Aslan A, Cakir A, Suleyman H, Karagoz Y, Bayir Y, Halici M. 2005. Antioxidant activity, reducing power and total phenolic content of some lichen species. Fitoterapia. 76.

Öztürk M., Ermin MD., Kivrak S., Mercan-Doğan N., Türkoglu A., Özler MA. 2011. In vitro antioxidant, anticholinesterase and antimicrobial activity studies on three Agaricus species with fatty acid compositions and iron contents: a comparative study on three most edible mushrooms. Food Chem. Toxicol. 49:13531360.

Pereira GA., Araujo NMP., Arruda HS., Farias DP., Molina G., Pastore GM. 2019. Phytochemicals and biological activities of mutamba (Guazuma ulmifolia Lamk.): a review. Food Res. Int. 126: 108713.

Prahastuti S., Hidayat M., Hasiana, ST., Widowati W., Widodo WS., Handayani RAS., Rizal R., Kusuma HSW. 2020. The ethanol extract of the bastard cedar (Guazuma ulmifolia L.) as antioxidants. Pharmaciana. 10 (1): 77-88.

Rafi M., Febriany S., Wulandari P., Suparto IH., Ridwan T., Rahayu S., Siswoyo DM. 2018. Total phenolics, flavonoids, and anthocyanin contents of six Vireya Rhododendron from Indonesia and evaluation of their antioxidant activities. J. Appl. Pharm. Sci. 8(9): 49-54.

Rafi M., Devi AF., Syafitri UD., Heryanto R., Suparto IH., Amran MB., Rohman A., Prajogo B., Lim LW. 2020. Classification of Andrographis 
paniculata extracts by solvent extraction using HPLC fingerprint and chemometric analysis. BMC Res. Notes. 13: 56-61.

Salazar-Arandra R., Perez-Lopez LA., Loppez Arroyo J., Alanis-Garza BA., Torres NW. 2009. Antimicrobial and antioxidant activities of plants from Northeast of Mexico. Evid. Based Complement Alternat. Med. 1-6.
Stalikas CD. 2007. Extraction, separation, and detection methods for phenolic acids and flavonoids. J. Sep. Sci. 30: 3268-3295.

Qingming Y., Xianhui P., Weibao K., Hong Y., Yidan S., Li Z., Yanan Z., Yuling Y., Lan D., Guoan L. 2010. Antioxidant activities of malt extract from barley (Hordeum vulgare L.) toward various oxidative stress in vitro and in vivo. Food Chem. 118(1): 84-89. 